\title{
Funding Economic Development and the Role of National Development Banks - The Case of Cyprus
}

\author{
Helen Kavvadia \\ Visiting research associate, Identités. Politiques, Sociétés, Espaces (IPSE), University of \\ Luxembourg, Luxembourg \\ helen.kavvadia@ext.uni.lu \\ Savvakis C. Savvides, \\ Visiting Lecturer, John Deutsch Institute for the Study of Economic Policy, Queen's \\ University, Canada \\ scsavvides@gmail.com
}

Development Discussion Paper: 2019 - 09

\begin{abstract}
The paper draws on previous research on the role of Multilateral Development Banks (MDBs), Regional Development Banks (RDBs) and National Development Banks (NDBs). It examines the role of the Cyprus Development Bank (CDB), prior its privatisation in 2008, in the economic development of the country and, specifically, its intermediation of international finance from multilateral and regional development banks. Currently, this function is undertaken by the commercial banks, which are however limited by a balance sheet fatigue, resulting from the excessive levels of private debt, as shown in this paper. Moreover, the commercial banks lack necessary elements in successfully executing this key role. They do not have the professional competence as well as the discipline and culture for executing such a highly demanding role in the economy. Last but not least, and judging from the experience of the CDB it is imperative to have a totally independent and competent financing institution, which will lead by example. Further to the analysis of the current macroeconomic and institutional context in Cyprus, there is a void of institutional capacity to fund projects and offer valuable advice to state and private decision-making bodies on decisive development projects. This paper recommends the establishment of an NDB or a National Development Finance Agency (NDFA), and proposes an appropriate model.
\end{abstract}

Keywords: National Development Banks, International Finance, Regional Development Banks, Multilateral Development Banks

Jel Classification: F45

Savvakis C. Savvides is an economist, specialising in economic development and project financing. He is a former senior manager at the Cyprus Development Bank and has been a regular visiting lecturer at Harvard University and at Queen's University. Author page: http://ssrn.com/author=262460.

Helen Kavvadia is Visiting Research Associate, at the University of Luxembourg-IPSE. Prior to this, she was a Senior Adviser at the Communications Department of the European Investment Bank (EIB). She teaches Europe and Global Economic Diplomacy, for the Master in European Governance of the University of Luxembourg.

Acknowledgments: We are grateful to the personalities that participated to our interview research and we thank them sincerely for their time, and valuable insights, that provided a wealth to our research. In particular the authors wish to thank George M. Georgiou and Les G. Manison for reading and editing the draft and for their valuable comments. 


\section{Introduction}

Cyprus has suffered two economic devastations in the past 50 years or so. Notably, the period after the Turkish invasion of the island in 1974, during which a major reconstruction process had to be undertaken, as well as in the current period following the wasteful investments in the years prior and after the 2013 bail-in, which left the country and its economic agents heavily indebted. It is worth contrasting and comparing these two periods that the country had to navigate through and overcome, thereby examining the role of the Cyprus Development Bank (CDB), the country's National Development Bank (NDB), in the post 1974 recovery and its absence in the post 2012 economic climate, given its privatization and change of profile in 2008. As the authors have been actively involved in the efforts for recovery from both calamities it is interesting to consider and report on the lessons learnt. Their similarities and differences regarding the challenges that these economic calamities presented and how appropriate/effective the efforts to recover and reconstruct the economy in each case were.

The devastation to the population and the economy, immediately after the invasion of 1974, was far greater than what was apparent in the aftermath of the bail-in in 2013. Following the invasion in Cyprus, more than one third of the population was forcefully ousted from their homes and their place of work. These people had to be accommodated and re-employed in what remained of the country, which was relatively underdeveloped compared to its captured and occupied part. Moreover, Cyprus as an oil dependent country had to face sky-rocketing oil prices following the 1970's oil-crisis, and the necessity for adapting its manufactured goods to European Community prerogatives resulting from the request of Cyprus to start talks for an Association Agreement with the EU in August 1970 (EIB, 1971: 143). Yet, an "economic miracle", as it was rightly described, was performed. How did this happen? What were the key factors that contributed towards rebuilding an economy that was in every respect shattered?

It is not the purpose of this article to consider and account for all the factors that played a role in this reconstruction and transformation of the economy in the years following 1974. However, we will highlight some distinct differences with the crisis of 2013 and why we think the latter proved to be a harder obstacle to overcome. First and foremost, although the impact on the balance sheets of households and companies from the 
massive loss of assets due to the invasion was very severe, private debt remained rather low. Any debts that were related to the occupied areas were suspended and people despite losing a substantial part of their assets in the occupied areas had a smaller but nevertheless clean balance sheet to start from and endeavour recovery. This is a key difference with the post-2013 era. The effort to rebuild the economy was surely very difficult, but the country had at least a clean slate from which to work and sound foundations on which to build again for a new prosperity. This was, of course, not enough by any means. Other things needed to be in place for a proper and lasting recovery to take place. The country needed sufficient sources of funding, but more importantly, the funding needed to be directed towards economically viable projects. And this is where the $\mathrm{CDB}$ was in position and ready to play a vital role. With the World Bank (WB) strengthening its initial 1972 loan support to the CDB prior to the 1974 Turkish occupation of part of the country, other Multilateral Development Banks (MDBs) and Regional Development Banks (RDBs), such as the European Investment Bank (EIB), the Council of Europe Development Bank (CEB), and Bilateral Development Banks (BDBs), such as the Kreditanstalt für Wiederaufbau (KfW) and the UK Export Credit (UKEC), were keen to provide advice and technical assistance, as well as funds and lines of credit. But, rightly, only on the condition that a proper evaluation of such capital investment proposals would demonstrate that the projects to be funded were economically viable and with a good repayment capability.

As stated in a World Bank report, in Cyprus "the Government, with the objective of making CDB the major instrument of development assistance to industry and tourism, restructured and refinanced CDB in 1976 with WB assistance". (WB, 1984:1)This was necessary as CDB lost more than half of its assets in the occupied north part of the island following the invasion and had to be rescued by the government but "retained the liabilities related to borrowings incurred to finance the projects" (WB, 1984:4). The "CDB became essentially a quasi-government institution, but its operational independence has been safeguarded in its Charter and in the adopted Statement of Policies and Procedures" (WB, 1984:4). As its profitability and solidity followed an ascending path, the government reduced its part in CDB's share capital. In 1991, CDB ceased to be $100 \%$ government owned, as the EIB, acquired $5.5 \%$ of CDB's share capital. In 1996, EIB's share capital was increased, and its minority shareholding was brought up to $12 \%$. But most importantly the MDBs/RDBs and to a far lesser extent 
the NDBs have been acting as CDB's primary funding sources. This allowed CDB to concentrate "exclusively at medium and long term, but (had) to borrow all its resources" (World Bank 1979:8). MDBs/RDBs, as back-to-back financiers, have been supporting $\mathrm{CDB}$ in its centre-stage role to reactivate the economy in the framework of three successive Cypriot Emergency Action Plans (EAPs) after the 1974 catastrophic events. They have been initially replenishing CDB's exhausted foreign-currency resources, and later, after its restructuring in 1976, supporting the government's efforts to improve the country's trade balance, by providing lines of credit to the CDB aimed towards funding both equity and debt for new and demonstrably economically viable investment projects in the foreign exchange earning private sector, mainly in export-oriented manufacturing and tourism. In addition, as gathered from various WB reports and interviews (WB 1979, WB 1984 and interview material), MDB/RDB support reinforced the already strong discipline and professional excellence and culture that existed at the $\mathrm{CDB}$ for a state-of-the-art investment appraisal and risk analysis.

The "quality shield" of MDB/RDB backing and the intermediation of their international finance allowed additional funding for such projects to flow in from the commercial banks, as soon as a CDB decision was taken to finance a major project. There were many such business opportunities both in the private and public sectors because there was a huge unmet demand in place. In its remit the CDB has been delivering. MDBs/RDBs appeared, though, having different views on CDB's role and activity. Some of them would have rather seen it involved as an NDB also on key infrastructure projects (interview material), whereas others aligned with the government supporting the focus on the private sector for constrained public spending in order to arrest public fiscal, current account and balance of payments deficit (WB, 1976: iii).

CDB acted as a catalyst for investment, and its role has been considered important for reactivating growth. Recognizing CDB's contribution for stimulating "dynamic and responsible entrepreneurship" (WB, 1976: iii), and using the recommendations of the "report on industrial opportunities survey mounted under UNIDO auspices" (WB, 1976:12), the MDBs/RDBs pushed the government for CDB's rehabilitation (WB, 1976:8). The rehabilitation has been opted as CDB's capital investment return of financed projects, as well as the repayment of its loans, were satisfactory. By the late eighties the economy was operating at full capacity, with low inflation and manageable 
external debt. Moreover, with GDP per capita reaching USD 4480 in 1985, the country was prospering again.

By contrast, the 2013 crisis came after 20 years of Cyprus promoting itself as an international financial centre and resulting in the banks dumping on the local economy unproductive loans mainly stemming from a great influx of foreign funds largely deposited in Cyprus banks. This was the key difference between the situation after the devastation of 1974 and the predicament the country and the economy found itself after 2012. The main difference was that private debt in 2013 was at a world record high, while the deposits were mostly owed to foreigners, meaning that the loans weighed most heavily on Cypriot economic entities.

In a small economy like Cyprus in 2019, private debt remains extremely high and it is still hard for a large number of households and firms to make ends meet, let alone service their existing loans. The only realistically possible objective for any remaining banks is to seek to maximise their return by using the only recourse available, which is, to use all means possible to capture any collateral and guarantees of existing nonperforming loans.

This is another important difference as compared to the challenges presented to the banking sector in 1974, where, despite the far bigger initial shock for the economy, people and businesses were relatively debt free and business opportunities were abundant. By contrast, in the more recent crisis, with the economy being choked up by debt, banks were left with no choice other than to seek to recover as much as possible from a huge pile of unproductive loans they were exposed to.

One may well ask: but why is this the only remaining purpose for banks in such circumstances? The reason is simple. A bank cannot grant a sufficient amount of new productive loans with adequate repayment capability in a faltering economy where there are not sufficient economic entities who can still be deemed credit worthy. Moreover, because of the huge private debt and the need to service unrepayable debts, there is insufficient domestic demand to allow for new and potentially viable investment opportunities to emerge.

In 2013 as in 1974, the World was in a recession. Unlike the previous crisis, however, at the recent crisis, Cyprus did not have in place a NDB, as the CDB had been previously privatised in 2008. While the importance of NDBs as institutional capacity 
and potent industrial policy instruments for economic resilience and development has been sufficiently stressed by MDBs/RDBs (WB 1973, WB 1976) ${ }^{1}$ and academic scholars (Stiglitz 2019, Xu et. Al. 2019, Naqvi et. Al. 2018, Mohieldin et. Al. 2018, Rubio 2018, Botta et. Al. 2018, Mertens \& Thiemann 2017, Griffith-Jones 2016, CGD 2016, Humphrey et. Al. 2015), the recent crisis brought about a resurgence of interest in NDBs, and led a number of countries around the world, developed as well as developing, independently of whether they never had a NDB, or had one and privatised it, to create them anew (Naqvi et. Al. 2018). Such countries include Portugal, Malta, Romania and Greece (Rubio, 2018). All of these countries have advanced the establishing process for a NDB, except Greece, where plans have not concretised. As a result, in the EU there are currently only two countries without such institutions (existing or under establishment) namely Greece and Cyprus, where the issue has not been even addressed.

While building upon existing bibliographic secondary sources on the cooperation of MDBs/RDBs with NDBs, the developmental role of the banking sector, and the economic history of the two major crises in the recent years in Cyprus, the study relied mainly on primary sources. These include relevant macroeconomic statistical figures, and data on the operation of the MDBs/RDBs in Cyprus, material from seven interviews with key officials of the MDBs/RDBs, the CDB and the Cyprus Ministry of Finance $(\mathrm{CMF})$, as well as from a Member of the Cypriot Parliament. Interview material has been collected in the period 01/05/2019 - 15/07/2019 and is based on personal or telephone semi-structured discussions. Unfortunately, statistical data could not be obtained from Cypriot sources, as CDB has been privatized, and the Central Bank of Cyprus (CBC) refused to provide information, on confidentiality grounds.

The case of Cyprus, is particularly revealing, as there are two crisis situations within forty years available for study: one, with a NDB in place, and the other without one. The paper posits that judging from the experience of the CDB it is imperative to have a totally independent and competent financing institution, which will lead by example. The scientific contribution of the study is twofold: First, it analyses the current macroeconomic and institutional context in Cyprus, demonstrating thereby a void of institutional capacity to fund projects and offer valuable advice to state decision-making

\footnotetext{
${ }^{1}$ The WB turned later mainly in the 1990's from an apologist to a disparager of NDBs, and back again after the 2009 crisis.
} 
bodies on key development projects. Second, it recommends the establishment of a NDB or National Development Finance Agency (NDFA), and proposes an appropriate model.

The remainder of the paper is organised as follows: Section two presents the role of the private debt in the current economic context in Cyprus, Section three demonstrates the need for an NDB/NDFA to spearhead economic recovery and development, and section four proposes an appropriate model for such an institution. The conclusion briefly summarises the main elements of the role of the $\mathrm{CDB}$, prior to its privatisation, in the economic recovery after the 1974 crisis and the development of the country and the current situation where this function is undertaken by the commercial banks, limited by a balance sheet fatigue and lacking necessary elements and expertise in successfully executing this key role. We therefore reiterate the need for the establishment of a NDB/NDFA.

\section{Private debt holding the economy to ransom}

Cyprus' total private debt in 2013 was at a world record high of about $350 \%$ of GDP (Figure 1). Moreover, while the loans weighed almost totally on Cypriot companies and households, as pointed out by Savvides (2016), the deposits were owed to a large extent to foreigners.

\section{Figure 1 - Private Debt as \% of GDP (2004-2015) by Corporations and Households}

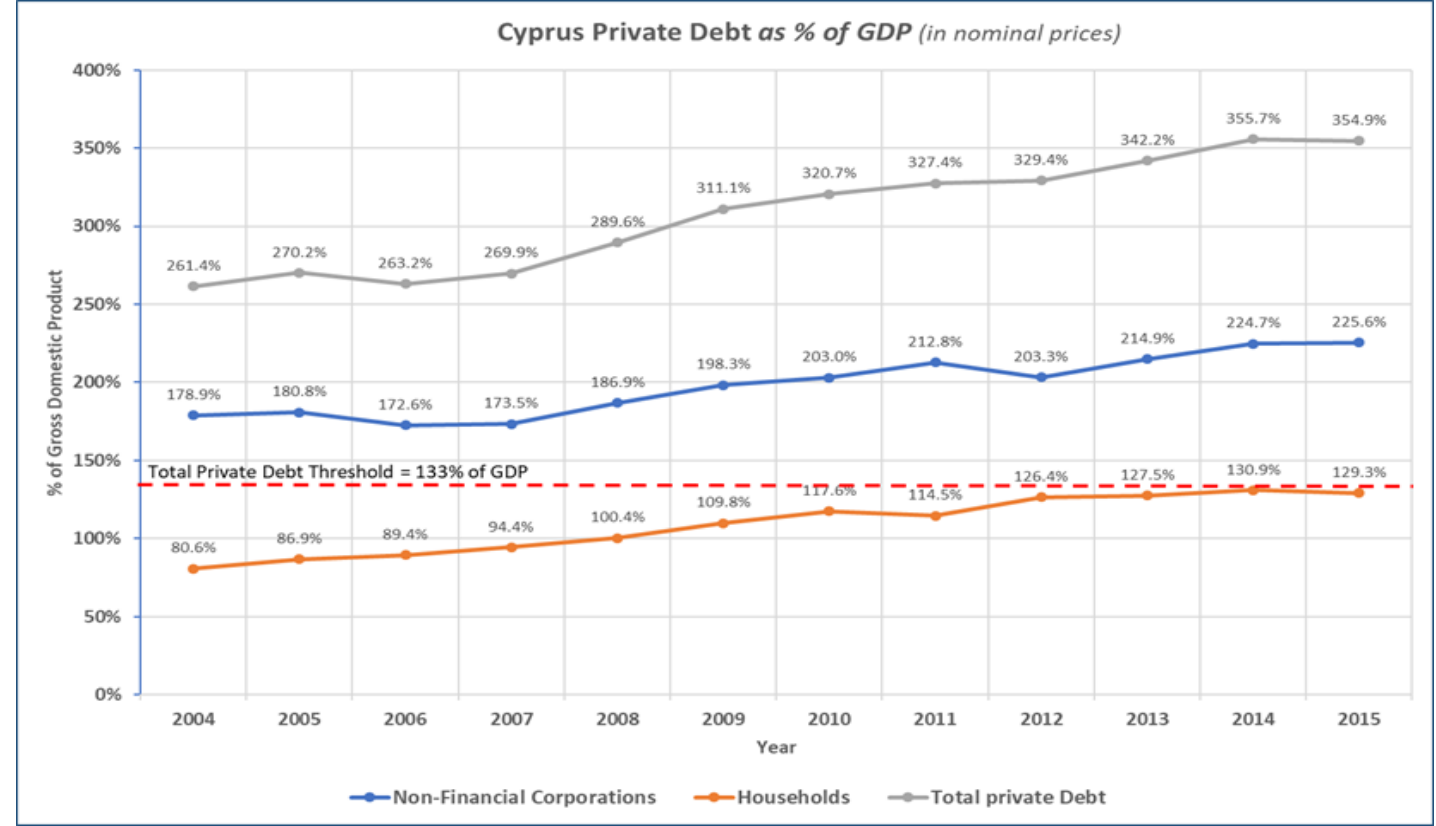

Source: http://ec.europa.eu/eurostat/web/macroeconomic-imbalances-procedure/private-sector-debt-consolidated 
Despite the window-dressing attempted by the administration through the legislative facilitation provided to banks to sell-off their loans and then pretending that private debt has been reduced, the actual total private debt remains as high as it ever was. Private debt rose from 330\% of GDP in 2012 to about 354\% in 2015 and it only marginally fell to $316 \%$ in 2017 (Figure 2). Private debt for Cyprus therefore has not been reduced and remains significantly above the levels of all the major EU countries, except Luxembourg which, however, is a totally different case as it has not internalised the risk as Cyprus has done. Luxembourg's private debt is mostly both owed and owned by foreign companies outside the country and hence it does not impact the local economy. Exactly the opposite of what is the case in Cyprus.

Figure 2 - Total Private Debt as \% of GDP (2004-2017) by selected EU countries

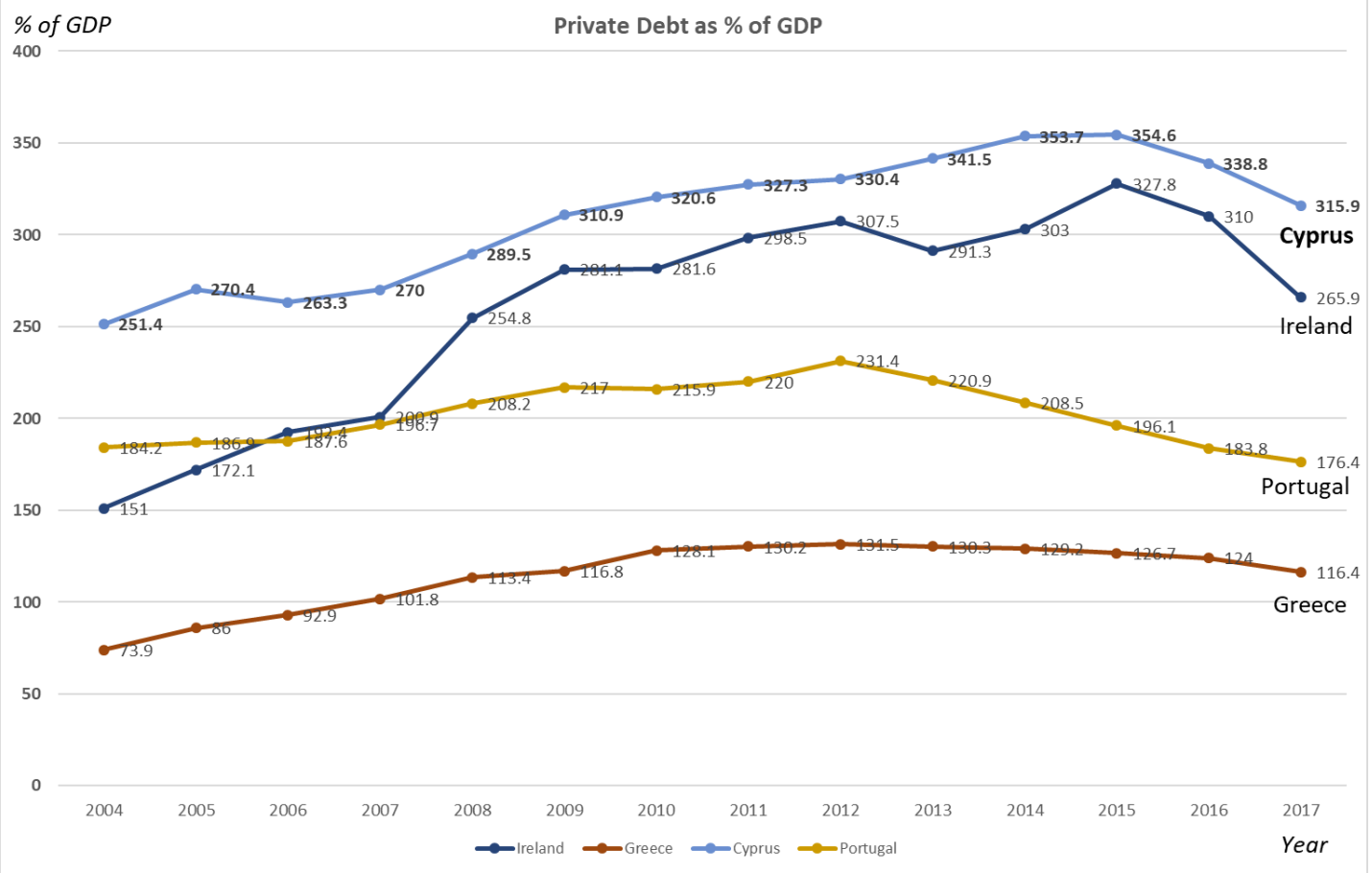

Source: http://ec.europa.eu/eurostat/web/macroeconomic-imbalances-procedure/private-sector-debt-consolidated

In conditions of excessive private debt (Figure 3), such as those currently existing in Cyprus, there are only very few potential borrowers who remain credit worthy and to whom new loans can be extended to. Moreover, because a large part of income needs to be channelled towards loan repayments ${ }^{2}$, domestic demand suffers as a result and, in turn, makes investment opportunities scarce and far between. In such situations, the

\footnotetext{
2 In a recent article published by Manison and Savvides (2017) it is demonstrated that Cyprus economic agents have been dissaving in order to support their consumption. Paradoxically, this has kept the economy from falling into a recession which, as Koo (2015) argues, will eventually happen when loan repayments are resumed.
} 
banks are unable to channel back productively into the economy new viable loans using the savings collected from repayments. The recourse route is, therefore, the only option available to be pursued by the banks and which translates into a transfer of wealth from the people to the banks. This further weakens the balance sheet position of the economic agents of the country and makes them even less credit worthy and less capable of receiving new funding. Inevitably, these circumstances bring about a recession (Koo, 2015), and secular stagnation (Hansen 1939, Summers 2014), either from the demandside (Dutt \& Ross 2007) or the supply-side (Gordon 2015).

These conditions are further aggravated by the evidenced core-periphery divergence in the Eurozone, attributed among others to the policy of the European Central Bank (ECB) for Quantitative Easing (QE) applied since January 2015 to stabilise the Eurozone financial markets and credit systems, while smoothing the fiscal adjustment necessity requested from national authorities, given that "only a limited part of fresh resources injected in peripheral economies via QE were eventually used to purchase domestic assets or to provide loans to domestic firms and households. On the contrary, a significant part of them took the form of capital flows "inflating" core economies" (Botta et al. 2018:20), while side-lining tools to smooth the economic cycle.

\section{Figure 3: The Economic and Financial Flows}

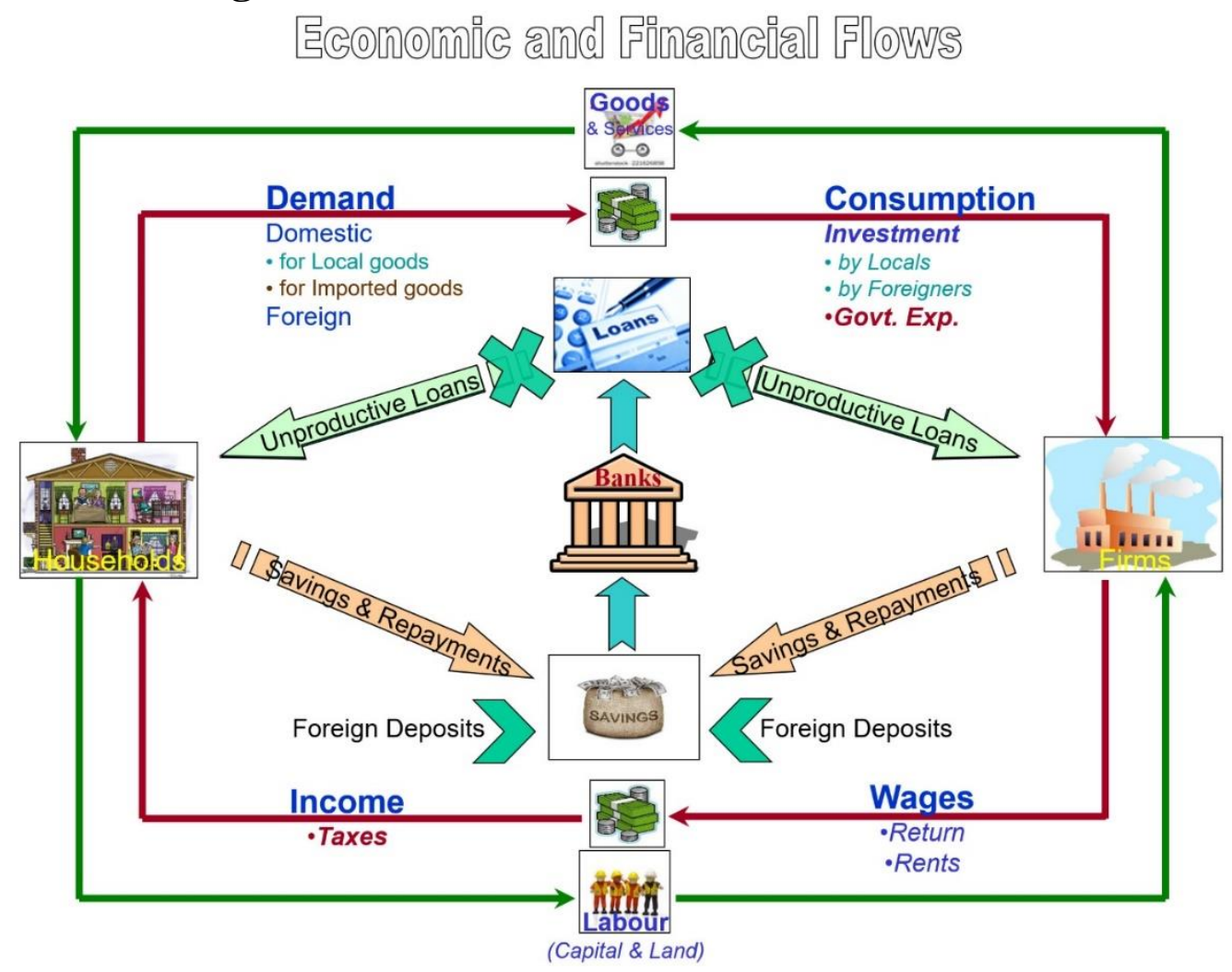


The requirement to finance economically viable investment projects and the need for a national development bank to spearhead economic recovery is vital in situations of excessive private debt. Sustained development results only from the productive use of economic resources to create real wealth. When conditions are conducive for productive investments, prudent funding facilitates the course of economic development. These conditions, however, do not currently exist in Cyprus. The very rapid growth of debt and the increasingly wasteful use of financial resources contributed to the events culminating in the financial crisis of 2013. The aftermath of this uncontrolled and unregulated expansion of credit was that the economy was left with a huge pile of unproductive loans and broken balance sheets for the economic agents of the country.

Many studies for advanced economies provide evidence that the fast growth of private debt leads eventually to a marked slowdown in economic growth as diminishing returns set in from the use of abundant finance (Mian and Sufi, 2014, Hudson, 2012, Vague, 2014). Most notably Koo (2015) coined the term 'balance sheet recession' to describe the recession that inevitably comes about from ignoring the problem of excessive private debt in an economy. Private debt weakens the two essential requirements necessary for an economy to grow and develop on a sustainable basis: the requirement for its economic agents to have clean balance sheets and, the lack of conditions conducive for viable investment, stemming from the excessive private debt and the inability to repay it. Excessive debt depletes equity and makes economic agents not credit worthy. And insufficient net income on a widespread scale creates conditions of feeble domestic demand, which in turn makes viable capital investment projects scarce and hard to find. This sets the economy on a downward spiral which, as Koo argues, results in a long and possibly deep balance sheet recession like the one Japan has experienced in the last few decades. This in turn, has been attributed as one of the factors leading to secular stagnation, as economies are unable to operate under full capacity due to structural weaknesses, triggering deficiencies in aggregate demand (Summers, 2014), other factors being, income inequality, diminishing technological prospects, and diminishing workforce. 
As the ECB, among other central banks that have been called upon to increase the resilience of the financial system and to lower the amplitudes of the financial cycle, have been rather concentrating on the first, while neglecting the second (Thiemann 2018), calls on increased institutional capacity have become increasingly vocal, especially for arresting "the diverging dynamics between the core and the periphery of the Eurozone" (Botta et. Al. 2018:23). The importance of industrial policy with increased role of MBBs/RDBs (Mohieldin et.Al. 2018, Humphrey et. Al. 2015, CGD 2016, Botta et. Al. 2018), as well as NDBs (Rubio 2018, Morozkina 2015, Humphrey et. Al. 2015, Manison \& Savvides 2017) has been stressed anew. This approach had been followed worldwide in the first decades of international concern for development and was promoted by the Bretton Woods institutions after 1948. In particular, the WB, pioneered the partnering with NDBs starting with the Development Bank of Ethiopia (DBE) in 1950 (WB 1976), a path-dependency approach has been subsequently followed by all MDBs/RDBs, which led them to use NDBs as intermediaries for channelling their funding to Small and Medium-sized Enterprises (SMEs) (WB 1976, Gordon 1983, CEB 2017, Lewenhak 2012, Unwin 1999). Intermediated finance through NDBs developed rapidly, and the WB from 6 partner NDBs in 1960, with a tenfold increase, reached 68 within 15 years, and volume-wise this activity ranged from $20-30 \%$ of annual lending volumes of MDBs/RDBs (WB 1976). This route to stimulate and restructure the private sector activity has also been successfully applied during the first Cyprus crisis, through the CDB (WB 1984, CMF 2019, CEB 2017 and interview material).

There are two contradictory schools of thought regarding how to deal with a failed economy that finds itself in extreme conditions of private (and public) debt. The predominant one, the neoclassical view, simply ignores private debt and argues that through a process of "creative destruction" new investment will take place and the bad will be replaced by the good. In other words, the market will work things out with no outside interference (Schumpeter 1942). The other school of thought, first raised by Minsky, is that private debt does not just go away, and certainly not without huge negative consequences for the economy and the welfare of its citizens (Minsky 1992). Cypriot policymakers however fully endorse the first approach and have embarked on a policy of saving the banks at any cost in the belief that by doing that the economy will eventually recover. But this, at best, is a myopic attempt to deal with the real problem, 
which is in fact the gargantuan private and mostly unproductive debt suffocating the economic agents of the country. Where would the economy recover from? In situations where private debt is widespread and overwhelming as it is currently in Cyprus, there is not much of the real economy left untouched or unaffected by the wasteful lending that preceded the crisis. Where conditions for viable/productive lending are not present, banks have no purpose other than seek to recover from the pledged assets and collaterals of the firms and households that received (or according to some commentators landed) with unproductive loans.

The consequence of ignoring private debt and facilitating the narrowly perceived needs of the major "opportunistic investors" in recapitalising a failed financial system is to create zombie banks like the ones Cyprus ended up having. Given that these financial institutions are condemned to operate in an economy that is overwhelmed with debt, their main and practically only remaining purpose for existence becomes one of extracting as much as possible from the collaterals and guarantees they hold in their books. They have, therefore, transformed themselves from being providers of finance to insolvency practitioners and asset management companies. Moreover, in addition to the need to raise aggregate demand there are reasons for overhauling institutional arrangements so that through appropriate industrial policy and institutional productive solutions the economy can restart because of viable investment projects (some in the public sector and through public private partnerships (PPPs)) which, through the existence of a NDA, can be identified, formulated and financed. Indeed, economic development results from capital investment being channelled towards viable businesses and projects and not from funding any non-viable investments" (Manison \& Savvides 2017). Thus economic development both depends on, and contributes to the growth and diversification of the financial sector. "The rate and character of development, meanwhile, are influenced by the priorities and efficiency of the sector's institutions and instruments which are the key mechanisms for adjustment and lubrication of an increasingly large, complex, and dynamic economic system" (Gordon 1983:5). It is imperative therefore to have in place a mechanism through which to utilise and refinance assets and released resources, including human capital, into new and potentially viable projects.

Commercial banks gradually replaced informal moneylenders starting in the $19^{\text {th }}$ century. Their basic function has been to assemble savings and provide funding mainly 
in the form of loans for high-yield bearing activities. They have traditionally concentrated to short-term lending (WB 1983, Morozkina 2015), and “...term lending runs counter to their institutional habits, attitudes, criteria, and procedures" (Gordon 1983:5).

This is certainly the case in Cyprus, where commercial banks do not have the capability to identify, evaluate and assess the risks of potentially economically viable projects. More specifically, the banks cannot do this on their own for the following reasons:

i) They do not have the necessary project finance training, tools and expertise;

ii) They cannot act as investment/development banks as they cannot be a lender and shareholder at the same time;

iii) A bank is not in a position to disentangle the complex web of funding of existing businesses. Most medium to large companies are financed by more than one bank where all hold different collaterals and undertakings on the same assets. In such situations it is almost impossible for a new financing structure proposed by one bank to gain the consent of the other;

iv) Even if it was possible for a bank to carefully convert part of its loans into equity funds (and assuming other banks would consent to go along with it), as noted above, it would be in a conflict of interests deadlock for a bank to act as both lender and shareholder at the same time;

v) The most significant negative impact of the uncontrolled and wasteful expansion of credit in Cyprus is that the equity capital base of Cyprus businesses (as well as for many households) has been almost completely depleted. The use of the recourse open to the banks to collect on their collaterals and guarantees is often presented as a cure to the economic woes of the country. However, as often remarked (Savvides 2016, 2015, 2014), this will lead to huge loss of value and a need for further recapitalisation it does nothing to tackle the root cause of the problem which is the restructuring and funding of viable economic projects in order to start rebuilding the economy on sound foundations.

The neglect and inability of commercial banks to pursue development policies has been the main reason for designing and establishing NDBs virtually across the world after WWII. These institutions were created to spearhead growth as well as diversification in the financial sector itself, "by being a laboratory, an example, and a source of 
initiative (NDBs) would facilitate the growth of a healthy, broadly based capital market" (Gordon 1983:7). "Development banks acted as the state's agent for allocating long-term credit to targeted industries considered vital for growth, but which the private sector was too risk-averse to finance" (Naqvi et Al. 2018: 3). It is "their long-term perspective in marked contrast to the short-term perspective that dominates in private financial markets- development banks can help design, fund, and coordinate expertise in specific areas of investment." (Stiglitz 2019:61).

Moreover, the intermediation of NDBs with MDBs/RDBs and their co-operation with commercial banks and other private sector actors can have considerable leveraging effect in the economy, through high multiplier effects of the way they fund projects, and the sectors they support (Griffith-Jones 2016). In Cyprus, this constitutes also the most important reason for an expert institution to lead the way for new and viable investment. This is because the object of the exercise should not be focussed on the "curing" of existing loans but rather on how to create new business structures in a project financing fashion which are not starved for new equity and can therefore have a viable and financeable business plan. In addition, a NDB can deal with many of the bigger loans to industry which as noted are entangled in a complex web of individual loans, collaterals and other securities (fixed and floating charges and personal guarantees) entered with many banks independently.

There is a need therefore to have a reliable mechanism in place which can ensure viability (adequate return and acceptable risk profile in order to enable the advent of new equity from potential investors) and to enable the banks to participate in such ventures and convert their debt into equity. This will reduce on one hand the burden for repayment and on the other it will give the participating financing institution a realistic share of the upside.

NDBs have been traditionally assuming the double role of financial institutions and development agents, as "they are not simply financial entities geared to the objective of profit maximization, subject to a risk constraint. NDBs are also committed to the goal of economic development" (WB 1973:18). Their intermediation of international finance takes the form of lines of credit received from MDBs/RDBs, which they subsequently channel to SMEs and/or smaller scale undertakings according to preagreed eligibility guidelines and conditions. As the intermediated funding is injected in the real economy at longer term maturities, and in some cases with tax exemptions, 
there are clear benefits for the final beneficiaries, including occasionally also lower interest rates. The NDB's role was, however, swept away and a lot of them have been abolished or sold, as a result of the neo-liberal euphoria's wave since the late 90's. NDB's have never been, however, an "étatist” policy instrument (WB 1973). A good number of them has been privately-owned, and all NDBs partnered with WB up to 1969 have had wholly or partly a private shareholding base (WB 1976). The share of public NDBs has been increasing subsequently, becoming a firm part of countries' development institutional capacity, aiming at "improved resource allocation and a distinct developmental impact" (WB 1976:3). At national level, NDBs have been promoting national macroeconomic and development goals, while at international level, their intermediation of MDB/RDB funding, has assured their alignment with global development objectives, key areas and practices, which in turn NDBs diffused in their domestic business community, often in the form of Technical Assistance (TA). The systematic screening of projects to be financed not only on financial merits, but also technical viability, environmental sustainability and economic impact in general (WB 1973), assured that projects financed had generally positive impact on the national economies and societies. A study of the WB in 1976 for example has shown, that projects financed through NDBs had an average Economic Rate of Return (ERR) of $23 \%$ on a sample of 160 subprojects studied (WB 1976:4). Furthermore, NDBs have often passed their knowhow to public policy makers and private sector actors, in the form of active advising or "leading by example", as part of a two-way process of mutual influence. Additionally, NDBs in many cases contributed to the development of domestic capital markets, as they broadened and diversified their sources of funds overtime, away from their original dependency on official resources (national, MDBs/RDBs, BDBs), which has been on average of some $80 \%$ of their funds (WB 1973:11).

The activity and role of CDB in Cyprus for the economic recovery after the Turkish invasion in 1974, and till its privatization in 2008 has been decisive and praised (CEB 2017, Kavvadia 2011, Unwin 1999, WB 1984, and interview material). The WB was the first MDB/RDB to start operations in Cyprus in 1963, and its operations ceased as Cyprus went up the development ladder, with its last loan approved in 1991. In its 30 years of operations the WB provided 30 loans in Cyprus, for an aggregate of USD 418,80 million. Of these, USD 14 million, i.e. $3 \%$ of the total, were for the private 
sector, using the CDB as its sole intermediation partner for three loans starting in 1972. WB viewed its impact through CDB as very satisfactory, with an average multiplier effect of $6 \%$. Alone through WB's last line of credit to CDB, of USD 5 million signed in 1979, 77 SMEs have been financed, creating and/or securing 850 jobs (WB 1983). The WB ceased its cooperation with the CDB in 1983, when the latter indicated that "further loans for its normal operations (were) not essential" (WB 1983:12). Cyprus became a member of CEB in 1963, but the bank started its operations in the country after the Turkish invasion, with the exception of a very small loan of EUR 1 million for reconstructing two villages after a natural disaster in 1969. Since starting its regular activity in Cyprus in 1976 and up until the privatization of the CDB in 2008, CEB had provided a total of EUR 2 billion in Cyprus, of which EUR 417 million, i.e. 21\% for the private sector, exclusively through the CDB. To May 2019 CEB has provided a total of EUR 2.4 billion in Cyprus, continuing its support for the country, which remains one of the ten largest borrowers of the bank (CMF 2019). No further loan has been provided, however, for the private sector, and no intermediation with another banking institution has been set in place after CDB's privatization. CEB was the largest source of multilateral funding for Cyprus, until 2001, when the EIB increased its activity in the pre-accession period, and later after the country's accession to the EU (CMF 2019). The EIB started its operations in Cyprus, in WB's phasing out period. Since 1981, the starting point of EIB's operations in the country till the privatization of the CDB in 2008, the EIB has provided a total of EUR 1,7 billion ${ }^{3}$ in Cyprus, mainly after the country's pre-accession period. Of this amount, EUR 127 million were through five lines of credit from EIB's own resources directly to the CDB, while a further line of EUR 4 million from risk capital budgetary resources was provided to the $\mathrm{CBC}$, and shared among $\mathrm{CDB}$ and two other financial institutions, namely the Popular Investment, and the Cyprus Investment and Securities Corporation (CISCO). EIB

\footnotetext{
${ }^{3}$ This finance has been made available under four Financial Protocols (1) attached to the EEC-Cyprus Cooperation Agreement. The Agreement signaled the intention of Cyprus and the EEC to strengthen economic and trade relations. Financial Protocols define the amount of funds to be made available, agreed by the EU and the country concerned. The amount available through the EIB consisted of EIB loans (EUR 142 million) and operations on risk capital budgetary resources (EUR 17 million) managed by the EIB on behalf of the EU Commission. In the framework of the Financial Protocols there was also grant aid available, provided through the European Commission. Besides this financing, Cyprus benefited from EUR 37 million of EIB loans under the Horizontal Protocol of the EU's Redirected Mediterranean Policy (1992-1996). From 1998 up to the country's accession to the EU in 2004, EIB financing has been provided under the Pre-accession facility.
} 
activity through the $\mathrm{CDB}$, prior to its privatization, "supported some 150 SMEs and secured some 1200 jobs in the private sector" (interview material). Recognizing CDB's role in private sector development in Cyprus, and wishing therefore to strengthen its capital structure, the EIB provided also a total of EUR 3 million from risk capital budgetary resources as participation in its share capital. The EIB became first CDB minority shareholder on behalf of the EU with $5.5 \%$ in 1991 by acquiring shares for EUR 1 million. When CDB ceased to be $100 \%$ government owned, in 1996, the EIB increased its minority share to $12 \%$, by acquiring shares of a total value of EUR 2 million from risk capital budgetary resources. In 2001, EIB's share was reduced to 6.13\% after the entrance of Piraeus Bank as strategic investor in CDB, through a capital increase, which also limited the government's share to $45 \%$. This shareholding structure change allowed Piraeus bank to control $37.8 \%$ and the CDB staff $1 \%$. At the same time, CDB's remit was extended to full-fledged banking operations, including deposits, for diversifying the bank's resources. Furthermore, this capital restructuring, enabled the entrance of CDB to the stock exchange and showed clearly the intention of the government for an increased private investor participation in CDB (interview material). This subsequently led to its full privatization in 2008, after "concerns on its relevance" (interview material) resulting from an "over-ambitious project pipeline, including satellite investments" (interview material) and reports on irregularities were voiced in 2005 (Stockwatch 2005). Beyond its multilateral financing intermediation role, the $\mathrm{CDB}$ has actively promoted the restructuring of the private sector through: i) strengthening the higher added-value and export-oriented manufacturing and services, as well as tourism in the country with a contribution averaging $10 \%$ of the GDFCF (WB 1983); ii) advising private investors (Savvides et Al. 1991) and the government, contributing to state-of-the-art due-diligence practices, innovative financial products (WB 1983 and interview material), and policy issues including the telecommunications sector and a national health scheme (CDB 2019), as well as managerial and IT issues through its subsidiary Novasys Information Services Ltd established in 1990 (CDB 2019); iii) contributing in the feasibility study for the creation of a stock exchange in Cyprus (interview material), especially as the EIB has 'considered issuing an EIB eurobond in Cyprus Pound' in 1998 (Unwin 1999); iv) breaking-through operations in environmental awareness and environmental impact assessment studies through its subsidiary Enalion Environmental Management Centre Ltd (EEMC) (Georghiou et Al. 1998) and international co-operations under the Mediterranean Environmental 
Technical Assistance Programme (METAP) (interview material); v) cooperating with international and European organisations and networks, such as the UNDP for strengthening the competitiveness of Cypriot industry, the International Investment Partners Scheme, (ECIP) through its EC Centre created in 1992 to provide advise on European funding opportunities for the domestic private sector (CDB 2019); vi) externalizing its know-how and experience through international co-operations, such as with the Palestinian Authority for the establishment of an NDB in Gaza/West Bank, which did not materialize (interview material), and the establishment of the Investment Bank of Kuban headquartered in Krasnodar in Russia in 1999, which was also the first cooperation of the $\mathrm{CDB}$ with the $\mathrm{EBRD}^{4}$, the latter holding $25 \%$ of the share capital, with the rest $75 \%$ in the hands of CDB (CDB 2019).

In the wake of the 2013 crisis in Cyprus, commercial banks took over the role of intermediating $\mathrm{MDB} / \mathrm{RDB}$ in the country. Funding was from the EIB and EBRD, as WB had ceased operations, and CEB has been providing funding in this period, solely for education and urban rural modernisation infrastructure projects. EBRD strengthened the capital structure of commercial banks, by taking up minority shareholdings in some banks, but not in CDB (in its private bank status). The EIB has injected funding to nine commercial banks ${ }^{5}$ of a total of EUR 853 million, i.e. $65 \%$ of the aggregate EIB financing in Cyprus in the period 2013-12/06/2019 (EIB 2019), reaching over 450 investment projects (EIB 2019). Despite this important support to the private sector, through the commercial banks, the EIB admits, however, investment barriers ${ }^{6}$ which are "preventing small businesses from reaching their full potential and identifying and tackling specific investment barriers that are crucial to unlock economic growth and job creation" (EIB 2018). These barriers are categorised as: i) Demand for products or services, ii) Availability of staff with the right skills, iii) Energy costs, iv) Access to digital infrastructure, v) Labour market regulations, vi) Business regulations

\footnotetext{
${ }^{4}$ Cyprus is a founding member of the EBRD, established in 1991. In 2014 EBRD started operations in Cyprus under the recipient country status for the period 2014-2020. "Until mid-2017, (EBRD) has invested approximately EUR 220 million in the private sector of Cyprus, in areas such as the funding of commerce, infrastructure, transport and renewable energy sources" (CMF 2019).

${ }^{5}$ The current EIB partner banks are: Alpha Bank Cyprus Ltd, Astrobank Ltd, Bank of Cyprus, Cyprus Development Bank, Eurobank Cyprus Ltd, Hellenic Bank Public Company Ltd, Cyprus, National Bank of Greece (Cyprus) Ltd, RCB Bank Ltd, Société Générale Bank - Cyprus, as of 26/06/2019 retrieved from https://www.eib.org/intermediarieslist/search/result?country=CY

${ }^{6}$ Barriers to investment for tangible and intangible capital (EIB 2017: 44).
} 
and taxation, vii) Availability of adequate transport infrastructure, viii) Availability of finance and ix) Uncertainty about the future (EIB 2017: 44). For Cyprus, although the country scores well in investment increase among the EU countries in $2017^{7}$, the EIB highlights as main barriers to investment, apart from the high energy costs (which is self-evident for an energy-wise non-interconnected island country completely dependent on oil imports), the investment uncertainty (EIB 2017: 44, EIB 2018). As for investment uncertainty, Cyprus is in the second place in the EU, after Greece and Slovakia that share the first place. Under investment uncertainty, apart from the macroeconomic concerns, the EIB includes elements "regarding the future path of demand, technology, and output and input market conditions" (EIB 2017:325), whereby under uncertainty about input markets, is considered also the uncertain access to finance, given that "credit-constrained firms are substantially more likely to cite uncertainty as impeding their investment activity" (EIB 2017:325). Access to finance is however, also one of the distinct categories of impediments to investment. As far as the impediment of access to finance is concerned, the country is at the third place among EU countries, after Greece and Malta (EIB 2017:44), although the EIB does not mention it as crucial for Cyprus. Disregarding the conceptual pitfall of the non-clearly delimited categorization, and given that difficulties in access to finance are encompassed in two categories of the EIB investment survey, one can surely draw the conclusion that apart from other elements of uncertainty, access to finance is the main impediment for investment in Cyprus, despite the strong support of the EIB in the banking sector. This is not surprising, as commercial banks are limited by a balance sheet fatigue, resulting from the excessive levels of private debt. Moreover, the commercial banks cannot play the desired by the EIB curing policy role of improving credit allocation based on the fundamentals of the return on investment, structural reform policies by less costly labour and capital reallocation and acting in "a system of pro-cyclical fund-raising and counter-cyclical investment spending from a preprioritised and authorised ledger of projects (which) could have a stimulating effect on investment without negative consequences for expectations of sustainability" (EIB 2017:325). Commercial banks lack the main pre-requisite for assuming this decisive

\footnotetext{
${ }^{7}$ In absolute terms, the largest increases were in Malta, the Netherlands, Cyprus, Denmark and Sweden, where investment in dwellings increased by more than 20\% in 2017. (EIB 2017:18).
} 
mission: it is not their raison d'être, nor their primary objective, which on the contrary is as with all private entities profit-making.

NDBs have therefore been playing an increasingly important role in the set-up and implementation of EU Financial Instruments (FIs) and budgetary guarantees, which "have witnessed a marked expansion in the last two Multi-Annual Financial Frameworks (MFFs) and they are called to play an even more significant role in the forthcoming MFF" (Rubio 2018: 5). Additionally, NDBs “consistently perform much better than private ones (commercial banks) in targeting the businesses that are more likely to genuinely need a guarantee" (Rubio 2018:6). They have proven to be effective not only in supplying the credit, but also correcting market failures, such as the information asymmetries among borrowers ${ }^{8}$, which imped particularly the long-term financing of enterprises. NDBs are therefore considered as key strategic partners in the implementation of the Investment Plan for Europe, usually referred to as "Juncker Plan" to counter and recover from the recent economic crisis, and namely the European Fund for Strategic Investments (EFSI). Around one-third of EFSI operations so far have already been mounted as co-financing deals with NDBs (Stiglitz 2019). Additionally, under the forthcoming MFF, NDBs will be entrusted with the implementation of FIs, along the EIB, which will, for the first time since its establishment, no longer be the exclusive managing authority ${ }^{9}$. Cyprus has currently no institution to participate to this "sources absorption dance" and intermediate international financing for development in Cyprus. Furthermore, and judging from the experience of the CDB it is imperative to have a totally independent and competent financing institution, which will lead by example. Further to the analysis of the current macroeconomic and institutional context in Cyprus, there is a void of institutional capacity to fund projects, intermediate international financing from EU and MDBs/NDBs sources, and offer valuable advice to state decision-making bodies on major development projects.

\footnotetext{
8 "The inability of a borrower to get access to funds at any interest rate, even though similarly situated borrowers do get credit" ( Stiglitz 2019:61).

9 "There are two types of FIs financed by the EU budget: centrally-managed FIs, which are set-up by EU regulations and financed by the European budget's general headings, and FIs under shared management, financed by member states' European Structural Investment (ESI) envelopes and set-up by national ESI managing authorities" (Rubio 2018: 5). NDBs can be entrusted ESI FIs, if they fulfil the criteria "to be considered an 'in house entity' according to article 12 of the EU public procurement Directive" (Rubio 2018: 6)
} 
It is up to Cypriot authorities, therefore, to seek the appropriate policy instruments, to facilitate private investment conducive to growth. Based on the renaissance of NDBs across Europe and the world (Stiglitz 2019, Xu et. Al. 2019, Rubio 2018), the paper proposes for Cyprus the creation of a special purpose financing and advisory institution, such as an NDB/DFA, possibly with the support and/or involvement of MDBs/RDBs and BDBs. Such an institution will be well placed to deal with the need to co-ordinate, support and refinance the restructuring of distressed businesses into new viable projects, as well as to catalyse conducive to growth investment through its intermediation of international MDBs/NDBs and EU financing. Additionally, such a new institution could along the lines of peer institutions (Xu et Al. 2019) also offer crucial advisory services to public and private sector project promoters, as well as an asset management company that can effectively deal with those bank assets that must be put on a smooth recovery process.

Figure 4 - National Development Bank (NDB) or Development Finance Agency (DFA) ${ }^{10}$

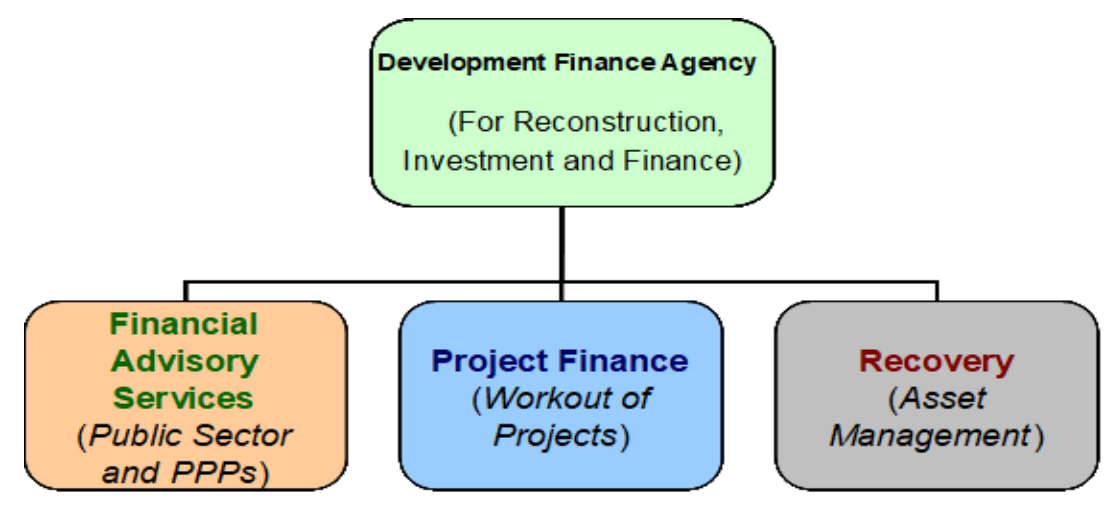

Source: Savvides (2016)

Within such an environment, the main systemic banks will concentrate on their healthy portfolio, while they should be ready to participate in project financing solutions put together in co-operation with the NDB/DFA. Preferably, these new Special Purpose Vehicle companies (SPVs) should be financed by a conversion of existing loans to equity and a syndicated loan agreement by the loan providers. The main criterion, however, would be economic viability and adequate repayment capability. With that as the key criterion, the Cypriot authorities can seek to provide any support necessary to enable and accelerate this process, which is focussed and leads to economic development.

\footnotetext{
${ }^{10}$ Savvides, S. (2016). Overcoming private debt (unblocking the loan burdened real economy in Cyprus), The Journal of Private Equity, Fall, Vol. 19, No. 4: pp. 51-59.
} 
An NDB/DFA can provide for the need to have solid and independent advice to the government on Public-Private Partnerships (PPPs), such as those provided by NDBs in many countries, as for example Ireland and the Netherlands, whose models the authors find quite appropriate for Cyprus. It is only a coincidence that the Irish model has been recommended to Cypriot authorities by the WB already back in 1987, as "the most desirable option (for institutional support for industrial development) would be the creation of an Industrial Development Corporation (IDC), combining features of such institutions as the Irish Industrial Development Authority..." (WB 1987: 30). Such professional institutions act as drivers for the financing of viable projects, as they also: i) have equity and quasi-equity instruments in place to support the need to replenish the depleted equity capital base of potentially viable businesses; ii) be manned by experts from Europe and Cyprus in project finance solutions. KfW, EIB and other such institutions may provide technical assistance so as to get the new bank up to speed quickly; iii) assist commercial banks and their existing customers to reach an amicable solution. This may include the selling of unproductive assets and the taking of equity positions to reduce the debt and enable the restructuring for potentially viable projects; iv) ensure that the main criterion for a project to be financed is to be viable and have sustainable repayment capability; v) work out the existing loans so as to find solutions, where some of the existing loans are converted to equity or repaid through sale of assets, or even with partial write-offs so it can attain viability statues and on the basis of that arrange an appropriate refinancing package.vi) enable the participating banks to have a share of the upside while they focus on their healthy loan portfolio and without disturbing their normal bank operations.

The NDB/DFA will serve a real and present need in the current state of the Cyprus economy. The need to identify and support viable new projects and businesses. It will be co-operating with existing banks and business clients as well as new investors (as illustrated in Figure 6) seeking to apply project finance type of solutions by formulating new viable business plans utilising the current resources and assets of existing debt laden companies. Successful and sustainable restructurings can only come about in most cases on the basis of new SPVs which are well capitalised and with a manageable debt. The current attempts to restructure the existing loans within the shell of the current balance sheets of existing companies is, in most cases, doomed to fail. The excessive and wasteful take up of debt during the "happy years" by these companies hinders and 
obstructs the viability and the possibility of striking a satisfactory repayment capability even for new potentially viable projects.

\section{Figure 5 - NDB/DFA to act as catalyst for the financing of viable projects}

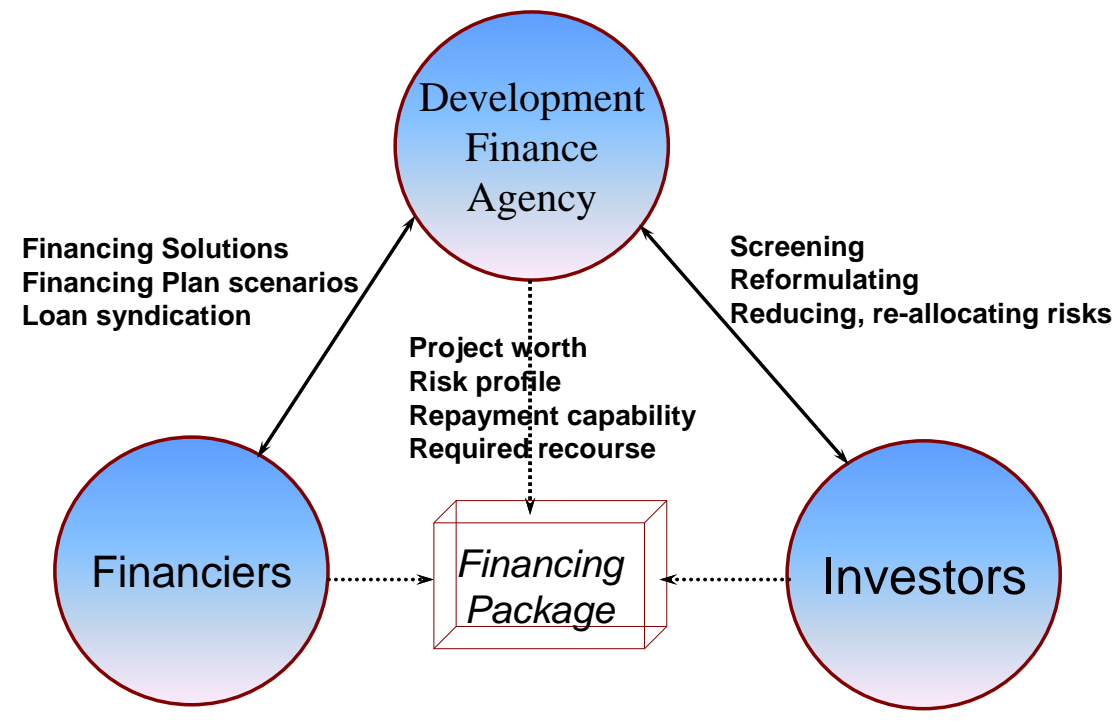

Source: Savvides (2016)

In this manner, credit-constrained firms will be substantially enabled to become more efficient and have their loan obligations reduced to the point where their survival is not constantly being threatened by excessive debt. If debt reduction is applied in a structured and professional manner, on a case-by-case basis, competitive but yet highly indebted companies can be presented with a path towards a normal and manageable funding structure often through a new SPV. Participating commercial banks can undertake to conditionally write off a pre-agreed amount of the existing loan balance in order to facilitate a restructuring and the NDB/DFA can match the same through a quasi-equity instrument. Through such viable restructurings competitive enterprises taking part in such a programme will be given a much-needed way to replenish their depleted equity.

The special purpose financing institution should have a strong capital base and lines of credit. Reformulated and potentially viable projects should be packaged as new corporate entities or SPVs and funded through both new and converted equity from old loans and/or through new long-term loan funds. The NDB/DFA should in this way be in a position to manage the need to have new foreign or local direct investment in newly defined investment projects. It will be also well placed to make the case for firms having 
an acceptable and manageable risk profile thus attracting new capital to enhance the new entities as healthy spin offs of the old ones. Additionally, the proposed solution contributes also to "red tape" reduction, as investors will have a 'one stop shop' for either acquiring distressed assets and/or for participating in new ventures in the newly reformulated and restructured projects. In this manner, the catalytic role and the intermediation of the NDB/DFA for international funding from MDBs/RDBs will once more prove itself decisive for the reconstruction of the Cypriot economy.

\section{Conclusions}

The economy of Cyprus needs a complete restart and a clean slate from which to start rebuilding. After the Turkish invasion of the island in 1974 the devastation was far greater. But other than country risk, an investor had no structural risks, such as that of an over-indebted economy, to worry about and take into account in undertaking an investment. The rebuilding could begin from day one. The CDB played an important role by intermediating international finance from MDBs/RDBs sources, developing and spilling over know-how and state-of the art capacity for catalysing private sector development. As a model institution CDB was ready to lead by example the bigger banks and guide funds towards economically viable projects, while demonstrating marked activism in capacity building, through advising and TA to both the public and the private sectors. It took a few years, but the country recovered and successfully rebuilt the economy from the ashes of war (including the legacy of 200.000 refugees). After CDBs privatisation in 2008, the developmental role has been entrusted mainly to the commercial banks, which are however limited not only by their scope, but also by balance sheet fatigue resulting from the excessive levels of private debt. The unprecedented and overwhelmingly high levels of private debt, the huge level of nonperforming loans and the scant and weakening local demand, after the 2013 economic crisis, are pushing currently seriously stifling the solid and sustained recovery of the Cyprus economy. Although the political and economic actors and the society as a whole do not acknowledge the urgency of the situation, a "courageous" policy intervention is needed for avoiding the exacerbation of the balance sheet "recession" and the impediments to productive investment in Cyprus, as the options and tools available for a swift recovery from such dire straits through conventional methods are severely limited and most likely insufficient. 
In an era of NDBs "renaissance", called to play a centre stage role in economic development through international cooperation established within an international network of MDBs/NDBs, to counter the alarming global challenges that are threatening growth and stability. Cyprus is currently among the two countries in the EU that have not adopted such an institutional set-up. This will also hamper its fertile uptake of the EU prospective FIs. In the current international and national context, the authors pose one possible solution and issue a call to action for the re-establishment of an NDB/NDFA, proposing also an appropriate model.

\section{Bibliography}

Black, W.K. (2005). The Best Way to Rob a Bank Is to Own One, 1st ed. University of Texas Press.

Botta, A., Tippet, B., \& Onaran, O. (2018). Core-periphery divergence and secular stagnation in the Eurozone. Macroeconomic evidence and policy proposals beyond unconventional monetary policy. FEPS policy paper. June 2018.

Center for Global Development (CGD). (2016). Multilateral Development Banks for this century's development challenges. Washington. CC. Retrieved on 20 April 2019 from https://www.cgdev.org/publication/multilateral-development-banking-for-thiscenturys-development-challenges.

Central Bank of Cyprus (CBC). Last accessed 05/05/2019 from http://www.centralbank.gov.cy.

Council of Europe Development Bank (CEB). (2017). Info. The quarterly magazine of the Council of Europe Development Bank. The quarterly magazine of the Council of Europe Development Bank. 12017.

Cyprus Development Bank. (2019). Last accessed on 24/04/2019 from https://www.cdb.com.cy/milestones-in-our-history.

Cyprus Ministry of Finance (CMF). (2019). Last accessed 24/06/2019 from http://mof.gov.cy/en/international-financial-institutions/institutions.

Diamond, W. \& Gulhati, R. (1973). Some reflections on the World Bank's experience with development finance companies (English). Staff working paper ; no. SWP 145. Washington, D.C.: The World Bank. Retrieved on 18/04/2019 from http://documents.worldbank.org/curated/en/884731468740126062/Some-reflectionson-the-World-Banks-experience-with-development-finance-companies.

Dutt, A.K. \& Ros, J. (2007). Aggregate demand schocks and economic growth. Structural Change and Economic Dynamics. Vol. 18 (1), pp. 75-99. 
European Investment Bank (EIB). (2019). Projects financed in Cyprus. Retrieved on 26/06/2019 from https://www.eib.org/en/projects/loans/index.htm.

European Investment Bank (EIB). (2019). EIB President confirms EUR 210 million Cyprus financing in 2018. 18 March 2019. Retrieved on 20/04/2019 from https://www.eib.org/en/press/all/2019-079-eib-president-confirms-eur-210-millioncyprus-financing-in-2018.

European Investment Bank (EIB). (2018). EIB Cyprus study highlights barriers to business investment and mixed investment ahead of Nicosia economic conference. 30 May 2018. Retrieved on 20/04/2019 from https://www.eib.org/en/press/all/2018-132european-investment-bank-cyprus-study-highlights-barriers-to-business-investmentand-mixed-investment-ahead-of-nicosia-economic-conference.

European Investment Bank (EIB). (2017). From recovery to sustainable growth. EIB Investment Report 2017/2018. 23 November 2017. DOI: 10.2867/48630. Retrieved on $20 / 04 / 2019$ from

https://www.eib.org/attachments/efs/economic_investment_report_2017_en.pdf.

European Investment Bank (EIB). (1971). Etats en voie de développement du Commoweath et Territoires dépendants du Royaume-Uni. Bref aperçu de la situation économique et capacité d'endettement. Etude economique-78B. 12/02/1971.

European Union. (2014). Statistics 2014. Retrieved last on 05/05/219 from http://europa.eu/about-eu/countries/member-countries/cyprus/index_en.htm.

European Union. (2014). Statistics 2014. Reprieved last on 05/05/2019 from http://europa.eu/about-eu/countries/member-countries/cyprus/index_en.htm.

Fisher, I. (1933). The Debt-Deflation Theory of Great Depressions. Econometrica, Vol. 1, No.4, pp. 337-357.

Georghiou, K., Delipetrou, P. \& Kadis, C. (1998). Special areas of conservation (directive 92/43/eec) in Cyprus. Retrieved on 09/05/2019 from https://www.researchgate.net/publication/324439128_SPECIAL_AREAS_OF_CONS ERVATION_DIRECTIVE_9243EEC_IN_CYPRUS.

Gordon, D. L. (1983). Development finance companies, state and privately owned : a review (English). Staff working paper ; no. SWP 578. Washington, D.C. : The World Bank. Retrieved on 17/04/2019 from http://documents.worldbank.org/curated/en/928181468741004629/Developmentfinance-companies-state-and-privately-owned-a-review.

Gordon, R.J. (2015). Secular stagnation: A supply-wide view. American Economic Review: Papers and Proceedings, Vol. 105 (5), pp. 54-59.

Griffith-Jones, S. (2016). Development banks and their key roles (Brot fur die Welt Discussion Paper No. 59. Retrieved 19/04/2019 from http://www.stephanygj.net/papers/Development_banks_and_their_key_roles_2016.pdf 
Hansen, A. (1939). Economics progress and declining population growth. The American Economic Review. Vol. 29 (1), pp. 1-15.

Harberger, A.C., \& Jenkins, G.P. (2000). Manual for Cost Benefit Analysis of Investment Decisions. Cambridge, Massachusetts: Harvard Institute for International Development.

Hudson, M. (2012). The Road to Debt Deflation, Debt Peonage, and Neo-feudalism. Working Paper No. 708, Levy Economics Institute of Bard College.

Humphrey, Chr. (2015). Developmental Revolution or Bretton Woods Revisited? The Prospects of the BRICS New Development Bank and the Asian Infrastructure Investment Bank. Working paper 418. April 2015. odi.org. Retrieved 19/04/2019 from https://owa.uni.lu/owa/\#path=/attachmentlightbox.

Jenkins, G.P. (1998). Evaluation of Stakeholder Impacts in Cost-Benefit Analysis. Harvard Institute for International Development, Development Discussion Paper No. 631.

Joshi, V. DPS. (1981). International adjustment in the 1980's (English). Staff working paper ; no. SWP 485. Washington, D.C. : The World Bank DPS. Retrieved on 17/04/2019 from http://documents.worldbank.org/curated/en/240151468767058403/Internationaladjustment-in-the-1980s.

Kavvadia, H. (2011). Investing in Cyprus: opportunities and challenges, Global Assets Magazine, Finance Publications Offshore, Jersey, UK, Spring 2011.

Keen, S. (2001). Debunking Economics: The Naked Emperor of the Social Sciences. Pluto Press Australia.

Koo, R., C. (2015) The Escape from Balance Sheet Recession and the Q.E. Trap, Wiley.

Koo, R. (2013). Balance sheet recession and the 'other half' of macroeconomics. European Journal of Economics and Economic Policies: Intervension. Vol. 10 (2), pp. 136-157.

Lewenhak, S. (2012). The role of the European Investment Bank . Routledge Library editions: Banking \& Finance. (Volume 20). ISBN 978-0-203-10824-6.

Manison, L., \& Savvides, S. (2017). Neglect private debt at the economy's peril. World Economics Journal, Vol. 18, No. 1, January-March 2017.

Mertens, D., \& Thiemann, M. (2017). Building a hidden investment state? The European investment bank, national development banks and European economic governance. Journal of European Public Policy, 1-21.

doi:10.1080/13501763.2017.1382556. 
Mian, A., \& Sufi, A. (2014). House of Debt: How They (and You) Caused the Great Recession, and How We Can Prevent It from Happening Again. University of Chicago Press.

Minsky, H.P. (1992). The Financial Instability Hypothesis. Levy Economics Institute of Bard College, Working Paper No. 74: 6-8. (May 1992).

Mohieldin, M., Subramaniam, N. \& Verbeek, J. (2018). Multilateral Development Banks must mobilize private finance to achieve the SDGs. Brookings, 19/07/2018. Retrieved on 23/04/2019 from https://www.brookings.edu/blog/upfront/2018/07/19/multilateral-development-banks-must-mobilize-private-finance-toachieve-the-sdgs/.

Morozkina, A. (2015). National and Multilateral DFIs in Russia and the impact of the BRICS New Development Bank. GEG Africa. BRICS insights paper 4. SAILA. Retrieved on 15 May from https://www.saiia.org.za/wpcontent/uploads/2015/04/BRICS-Insights-4.pdf.

Naqvi, N., Henow, A. \& Chang, H. (2018). Kicking away the financial ladder? German development banking under economic globalisation, Review of International Political Economy, DOI: 10.1080/09692290.2018.1480515

National Development Finance Agency. Ireland. Retrieved last on 05/0/2019 from http://www.ndfa.ie/home.html.

Rubio, E. (2018). Making better use of public funding the role of national promotional banks and institutions in the next EU budget. Notre Europe. Jacques Delors Institute. Report no. 115. July 2018.

Savvides, S. (2019), The Advent of Zombie Banks (January 20, 2019). Available at SSRN: https://ssrn.com/abstract=3319902 or http://dx.doi.org/10.2139/ssrn.3319902

Savvides, S. (2016). Overcoming private debt (unblocking the loan burdened real economy in Cyprus), The Journal of Private Equity, Fall, Vol. 19, No. 4: pp. 51-59.

Savvides, S.C.(2015). What Lies Beneath? Truth and Lies about the Cyprus Economy. Accountancy Cyprus, Vol. 121, (December 2015).

Savvides, S.C. (2014). The Pursuit of Economic Development, Journal of Finance and Investment Analysis, Scienpress, Vol. 3, No. 2, (2014).

Savvides, S.C. (2011). Corporate Lending and the Assessment of Credit Risk. Journal of Money, Investment and Banking, Issue 20, (March 2011).

Savvides, S.C. (1994). Risk Analysis in Investment Appraisal, Project Appraisal Journal, Vol. 9, No. 1, (March 1994).

Schumpeter, J. (1942). Capitalism, Socialism and Democracy. Harper \& Brothers. 
Stiglitz, J.E. (2019). Rewriting the rules for the European economy. Foundation for European Progressive Studies (FEPS), Brussels, Report dated 21 March 2019. ISBN Nr 978-2-930769-25-7.

Stockwatch. (2005). Revealing report on CDB. 26/01/2005 at 10:56. Retrieved on 14/04/2019 from https://www.stockwatch.com.cy/en/article/oikonomia/revealingreport-cdb.

Summers, L. (2014). U.S. economic prospects: Secular stagnation, hysteresis, and the zero lower bound. Business Economics. Vol. 49 (2), pp. 65-73.

Thiemann, M. (2018). Is resilience enough? The macroprudential reform agenda and the lack of smoothing of the cycle. Public Administration 2018. pp 1- 15. https://doi.org/10.1111/padm.12551.

Unwin, B. President. (1999). Cyprus on the way to accession: the role of the Europea, Investment Bank. European Investment Bank. Cyprus business guide: $10^{\text {th }}$ Anniversary Conference "Cyprus towards the European Union", Cyprus Hilton, Nicosia, 3 May 1999.

Vague, R. (2014). The Next Economic Disaster, University of Pennsylvania Press.

Vague, R. (2014). The Next Economic Crisis: Why It's Coming and How to Avoid It, University of Pennsylvania Press.

Vague, R. (2014). Government Debt Isn't the Problem—Private Debt Is, 9 Sept 2014. Retrieved last on 05/05/2019 from

http://www.theatlantic.com/business/archive/2014/09/government-debt-isnt-theproblemprivate-debt-is/379865/.

World Bank (WB). Projects financed in Cyprus. Retrieved on 17/04/2019 from http://projects.worldbank.org/search?lang=en\&searchTerm $=\&$ countrycode_exact $=C Y$

World Bank (WB). (1993). Cyprus - Environmental review and action plan (English). Washington, DC: World Bank. Retrieved on 21/04/2019 from http://documents.worldbank.org/curated/en/539691468246575249/CyprusEnvironmental-review-and-action-plan.

World Bank (WB). (1987). Cyprus - A long-term development perspective (English). A World Bank country study. Washington, D.C. : The World Bank. Retrieved on 20/04/2019 from http://documents.worldbank.org/curated/en/315841468749754358/Cyprus-A-longterm-development-perspective.

World Bank (WB). (1986). Cyprus - A long-term development perspective (English). Washington, DC: World Bank. Retrieved on 20/04/2019 from http://documents.worldbank.org/curated/en/370511468246905423/Cyprus-A-longterm-development-perspective. 
World Bank (WB). (1985). Cyprus - Country economic memorandum (English). Washington, DC: World Bank. Retrieved on 20/04/2019 from http://documents.worldbank.org/curated/en/774321468244507005/Cyprus-Countryeconomic-memorandum.

World Bank (WB). (1984). Project completion report. Cyprus: third loan to the Cyprus Development Bank. (Loan 1744-CY). June 12, 1984. Retrieved on 17/04/2019 from http://documents.worldbank.org/curated/en/884821468260125323/pdf/multi-page.pdf.

World Bank (WB). (1983). Cyprus - Current economic positions and prospect for growth during the five-year plan 1982-86 (English). Washington, DC: World Bank. Retrieved on 17/04/2019 from http://documents.worldbank.org/curated/en/498571468027641735/Cyprus-Currenteconomic-positions-and-prospect-for-growth-during-the-five-year-plan-1982-86.

World Bank (WB). (1980). Cyprus - Country economic memorandum (English). Washington, DC: World Bank. Retrieved on 17/04/2019 from http://documents.worldbank.org/curated/en/194271468031769080/Cyprus-Countryeconomic-memorandum.

World Bank (WB). (1979). Staff appraisal report on a third loan to the Cyprus Development Bank. Document for official use only. June 14, 1979. Retrieved on 17/04/2019 from http://documents.worldbank.org/curated/en/502181468026050784/pdf/multi-page.pdf.

World Bank (WB). (1979). Report and recommendation of the president of the IBRD to the executive directors on a proposed loan to the Cyprus Deveopment Bank Ltd with the guarantee of the Republic of Cyprus for a third development bank project. Document P-2598-CY. June 14 1979. Retrieved on 17/04/2019 from http://documents.worldbank.org/curated/en/415631468031531819/pdf/multi-page.pdf.

World Bank (WB). (1976). Development finance companies (English). Sector policy paper. Washington, DC : The World Bank. Retrieved on 19/04/2019 from http://documents.worldbank.org/curated/en/317061468763754287/Developmentfinance-companies.

World Bank (WB). (1976). Cyprus - Country economic memorandum (English). Washington, DC: World Bank. Retrieved on 17/04/2019 from http://documents.worldbank.org/curated/en/385661468031766418/Cyprus-Countryeconomic-memorandum.

World Bank (WB). (1971). Cyprus - Current economic position and prospect (English). Europe, Middle East \& North Africa series; no. EMA 41. Washington, D.C. : World Bank Group. Retrieved on 19/04/2019 from http://documents.worldbank.org/curated/en/639821468244506056/Cyprus-Currenteconomic-position-and-prospect.

Xu, J., Ren, X. \& Wu, X. (2019). Mapping Development Finance Institutions Worldwide: Definitions, Rationales, and Varieties. Institute of New Structural Economics, Peking University, NSE Development Financing, Research Report No 1, 
May 2019. Retrieved on 22/06/2019 from https://www.researchgate.net/publication/333809057_Mapping_Development_Financ e_Institutions_Worldwide_Definitions_Rationales_and_Varieties_The_New_Structur al_Economics_Development_Financing_Research_Paper_Series_aims_to_build the first_comprehensive_d. 